\title{
Hour Times Milligram Per Milliliter Per Milligram Per Gram
}

National Cancer Institute

\section{Source}

National Cancer Institute. Hour Times Milligram Per Milliliter Per Milligram Per Gram. NCI

Thesaurus. Code C117920.

Hour times milligram per milliliter, divided by milligram per gram. 